\title{
Synthesis, bioactivity and Docking Study of Some New Indole- hydrazone Derivatives
}

\author{
N. Sharaf El-Din ${ }^{\mathrm{a}^{*}}$, A. Barseem ${ }^{\mathrm{b}}$ \\ ${ }^{a}$ Department of Pharmaceutical Chemistry, Faculty of Pharmacy, Tanta University, El Gish street, 31527, Tanta, Egypt. \\ ${ }^{b}$ Department of Pharmaceutical Chemistry, Faculty of Pharmacy, Kafrelsheikh University, Kafrelsheikh, Egypt.
}

\begin{tabular}{l} 
ARTICLE INFO \\
\hline Article history: \\
Received on: $30 / 06 / 2016$ \\
Revised on: 07/09/2016 \\
Accepted on: 20/10/2016 \\
Available online: 28/12/2016 \\
\hline Key words: \\
Indole, Hydrazone, \\
Anticancer, Anti- \\
inflammatory, molecular \\
docking, drug likeness and \\
bioactivity.
\end{tabular}

\begin{abstract}
In the present study, a series of new indole-hydrazone derivatives were synthesized. The structures of the synthesized compounds were established on the basis of elemental and spectral (IR and ${ }^{1} \mathrm{H}-\mathrm{NMR}$ ) studies. All synthesized compounds were screened for their anti-inflammatory against carrageenan induced oedema in albino rats at a dose of $0.2 \mathrm{mmol} / \mathrm{kg}$ using indomethacin as a standard drug. The reduction in oedema formation was ranged between $72.3-89.3 \%$ for all the synthesized compounds compared to indomethacin (46\% inhibition). Moreover, their anticancer activity against breast cancer cell line (MCF-7) at a dose of $100 \mu \mathrm{g} / \mathrm{ml}$ was evaluated. The compounds $\mathbf{2 f}$ and $\mathbf{2 j}$ showed mild anticancer activity (61\% and $68 \%$ inhibition, respectively) compared to doxorubicin. Furthermore, all molecules were docked to the active site of both cox-1 and cox-2 using the docking program Molego virtual docker. All prepared compounds showed high docking score against both cox-1 and cox-2. The dock scores and binding energy were found to be in good agreement with the pharmacological results. Finally, the drug likeness and bioactivity were predicted using Molinspiration software. The results revealed that all new compounds show good drug likeness score and bioactivity score.
\end{abstract}

\section{INTRODUCTION}

Non-steroidal anti-inflammatory drugs (NSAIDs) are a diverse class of drugs commonly used for the treatment of inflammatory conditions, analgesia and fever with little side effects to gastrointestinal tract as well as relieving the pains of everyday life. Therefore, there is an increasing interest in the research and development of selective COX- 2 inhibitors (Dannhandt and Kiefer, 2001; Pratico and Digne, 2005). Notably, epidemiological and clinical studies suggest that non-steroidal anti-inflammatory drugs (NSAIDs), including, cyclooxygenase (COX)-2 selective inhibitors, reduce the risk of developing cancer (Chan, 2002; Thun et al, 2002). Moreover, selective COX-2 inhibitors may demonstrate new important therapeutic benefits as anticancer agents, as well as preventing premature labor and perhaps even retarding the progression of Alzheimer's

\footnotetext{
* Corresponding Author

E-mail: nsharafd @ gmail.com
}

disease (Aisen, 2002). Literature survey reveals that hydrazones and their derivatives are providing valuable therapeutic class in organic chemistry. These compounds have interesting biological properties, such as anti-inflammatory, analgesic, anticonvulsant, anti-tuberculous, antitumor, anti-HIV and antimicrobial activities (Rollas and Kucuk Guzel, 2007; Babahan et al., 2013). Further, It is evident that the $\mathrm{C}=\mathrm{N}$ linkage in azomethine derivatives is essential structure requirement for biological activity (Vinusha, 2015) such as, antimicrobial (da Silva et al., 2011), antibacterial (Vashi and Naik, 2004), anticancer (Kuz'min et al., 2005). It has been reported that indole and its derivatives are an important class of bioactive molecules in the field of drugs and pharmaceuticals areas including, anti-inflammatory (Sondhi et al., 2006, Bhati and Kumar, 2008; Hemalatha et al., 2013), antimalarial (Santos, 2015), antimicrobial (Karekal et al., 2013; Bhaskar et al., 2007), antiviral (Tichý et al., 2012), antibacterial (Tiwari et al., 2006), antifungal (Guiqing et al., 2016), anticancer (Kumar and Kumer, 2013; Macdonough et al., 2013) and antioxidant activities (Estevão et al., 2010). 
<smiles>N/N=C/c1c[nH]c2ccccc12</smiles><smiles>N/N=C/c1c[nH]c2ccccc12</smiles>
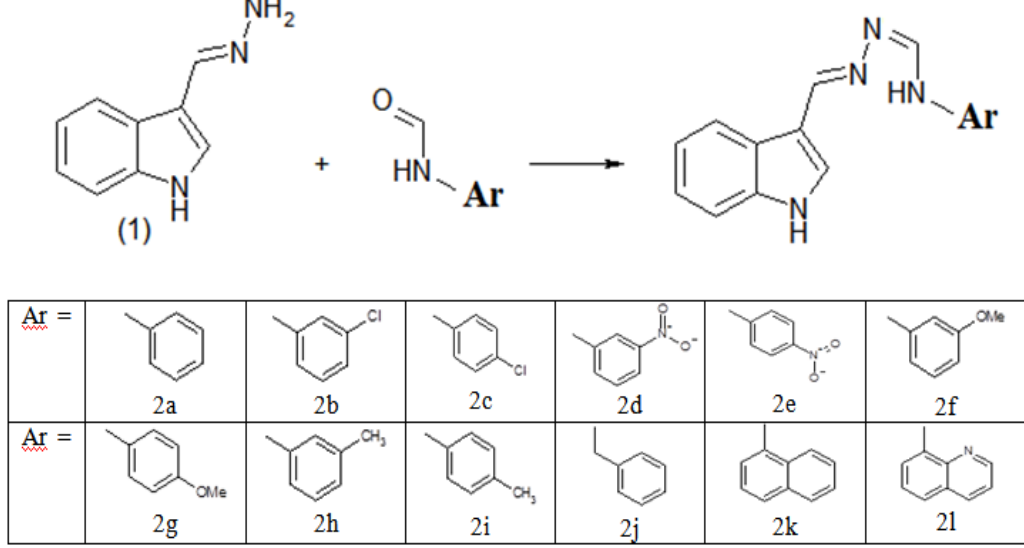

Scheme 1: The synthetic route for preparation of a series of new indole-hydrazone derivatives (2a-2l)

Keeping in view of biological importance of the three molecular moieties viz., indole, hydrazone and azomethine group, it has been felt worthwhile to synthesize as depicted in Scheme I. We wish in the present work to generate new leads by synthesize indole-hydrazone derivatives in the hope of obtaining better antiinflammatory and anticancer agents. Further, the molecular docking were studied to help in understanding the various interactions between our derivatives and enzyme active sites (cox1 and cox-2) as well as the correlation between docking studies and the in vivo/in vitro studies. In addition, the drug likeness and bioactivity were evaluated for all prepared compounds.

\section{MATERIAL AND METHODS}

\section{Chemistry}

All melting points were determined with a Kofler Block apparatus. The progress of the reactions was monitored by thin layer chromatography (TLC) using aluminum silica gel plates $60 \mathrm{~F}$ 245 and further purification was performed using column chromatography (silica gel, 70-230 mesh). IR spectra were recorded on a Perking Elmer 1430 ratio recording infrared spectrophotometer with CDS data station using $\mathrm{KBr}$ Wafer technique at the Central Laboratory, Tanta University, and The ${ }^{1} \mathrm{H}$ NMR spectra were recorded on a Varian Gemini-300 BB Spectrometer at $300 \mathrm{MHz}$ with TMS as a standard, and Elemental Analysis at the Micro Analytical Center, Cairo University, Cairo, Egypt. Chemicals and solutions were purchased from Merck Co. and they were in reactive grade.

\section{$1 \mathrm{H}$-indole-3-carbaldehyde hydrazone (1)}

Equimolar quantities of hydrazine hydrate $(1 \mathrm{ml}, 0.02 \mathrm{~mol})$ and indole-3-carbaldehyde $(2.9 \mathrm{~g}, 0.02 \mathrm{~mol})$ were dissolved in $50 \mathrm{ml}$ of absolute ethanol. The mixture was refluxed for $9 \mathrm{hr}$.

After the completion of the reaction (as monitored by TLC), the excess of solvent was removed under reduced pressure. The obtained product was recrystallized with ethanol (Lohitha, et al., 2011).

\section{General procedure}

Suspend 1H-indole-3-carboxaldhyde hydrazone (1) $(0.01$ mol) in absolute ethanol $(20-40 \mathrm{ml})$. To the previous mixture $\mathrm{N}$ substituted formamide $(0.01 \mathrm{~mol})$ was added gradually. The mixture was refluxed with stirring for 16 - $30 \mathrm{hr}$. After TLC monitoring using chloroform : ethyl acetate $(9: 1)$ or n-hexane : ethyl acetate 8:2(v/v) as eluent, the solution was cooled to $5{ }^{\circ} \mathrm{C}$ in ice bath.

The product formed was filtered, washed with cold water, purified by silica gel column chromatography using chloroform as eluent, then the solvent was evaporated and the product was recrystallized from ethanol to yield the corresponding compounds.

\section{$N^{\prime}-((1 H$-indol-3-yl)methylene)- $N$-phenylformohydrazon-amide}

(2a)

The compound 2a was obtained as yellow powder, yield of 78\%; M.p.> $300{ }^{\circ} \mathrm{C}$; IR $\left(\mathrm{KBr}, v_{\max }\left(\mathrm{cm}^{-1}\right)\right)$ : $1577(\mathrm{C}=\mathrm{C}), 1620$ $(\mathrm{C}=\mathrm{N}), 3214(\mathrm{NH}) ;{ }^{1} \mathrm{H}-\mathrm{NMR} \quad\left(300 \mathrm{MHz}, D M S O-\mathrm{d}_{6}, \delta \quad(\mathrm{ppm})\right)$ : 7.151-7.486 (m, 9H, Ar-H), 8.335 (d, 2H, , J= 7.5Hz, Ar-NH, N$\mathrm{CH}=\mathrm{N}), 8.904(\mathrm{~s}, 1 \mathrm{H}$,indole $\mathrm{H}-2), 11.652(\mathrm{~s}, 2 \mathrm{H}$, indole $\mathrm{NH}$, $\mathrm{CH}=\mathrm{N}$ ); Elemental analysis: Calc. for $\mathrm{C}_{16} \mathrm{H}_{14} \mathrm{~N}_{4}$ : C, 73.26; H, 5.38; $\mathrm{N}, 21.36$; found: C, $73.38 ; \mathrm{H}, 5.10 ; \mathrm{N}, 19.82 \%$. 
$N^{\prime}$-((1H-indol-3-yl) methylene)-N-chlorophenyl)formohydrazonamide (2b)

The compound $\mathbf{2 b}$ was obtained in the yield of 85\%; M.p. $300{ }^{\circ} \mathrm{C}$; IR $\left(\mathrm{KBr}, v_{\max }\left(\mathrm{cm}^{-1}\right)\right)$ : $1577 \quad(\mathrm{C}=\mathrm{C})$, $1620(\mathrm{C}=\mathrm{N}), 3215(\mathrm{NH}) ;{ }^{1} \mathrm{H}-\mathrm{NMR} \quad\left(300 \mathrm{MHz}, D M S O-\mathrm{d}_{6}, \delta\right.$ (ppm)): 7.174-7.911 (m, 8H, Ar-H), 8.339 (d, 2H, , $J=7.5 \mathrm{~Hz}$, Ar- $\mathrm{NH}, \mathrm{N}-\mathrm{CH}=\mathrm{N}$ ), 8.907 (s, $1 \mathrm{H}$,indole H-2), 11.657 (s, $2 \mathrm{H}$, indole $\mathrm{NH}, \mathrm{CH}=\mathrm{N}$ ) ; Elemental analysis: Calc. for $\mathrm{C}_{16} \mathrm{H}_{13} \mathrm{ClN}_{4}$ : C, 64.76; H, 4.42; N, 18.88; found: C, 65.02; H, 4.63; $\mathrm{N}, 19.10 \%$.

\section{$N^{\prime}-((1 H-i n d o l-3-y l)$ methylene $)-N-(4-c h l o r o p h e n y l)-$ formohydrazonamide (2c)}

The compound $2 \mathbf{c}$ was obtained in the yield of $80 \%$; M.p. $298^{\circ} \mathrm{C}$; IR $\left(\mathrm{KBr}, v_{\max }\left(\mathrm{cm}^{-1}\right)\right): 1577(\mathrm{C}=\mathrm{C}), 1619(\mathrm{C}=\mathrm{N}), 3213$ $(\mathrm{NH}) ;{ }^{1} \mathrm{H}-\mathrm{NMR}$ (300 MHz, DMSO-d $\left.{ }_{6}, \delta(\mathrm{ppm})\right): 7.172-7.910(\mathrm{~m}$, 9H, Ar-H), 8.331 (d, 2H, , J= 7.5Hz, Ar-NH, N-CH=N), 8.899 (s, $1 \mathrm{H}$,indole $\mathrm{H}-2), 11.649(\mathrm{~s}, 2 \mathrm{H}$, indole $\mathrm{NH}, \mathrm{CH}=\mathrm{N})$;Elemental analysis: Calc. for $\mathrm{C}_{16} \mathrm{H}_{13} \mathrm{ClN}_{4}$ : C, 64.76; H, 4.42; N, 18.88; found: C, 64.94; H, 4.43; N, $18.97 \%$.

\section{$N^{\prime}-((1 H-i n d o l-3-y l)$ methylene)-N-(3-nitrophenyl)formo- hydrazonamide (2d)}

Compound 2d was obtained in the yield of $85 \%$ as yellow crystalline product; M.p. $300{ }^{\circ} \mathrm{C}$; IR $\left(\mathrm{KBr}, v_{\max }\left(\mathrm{cm}^{-1}\right)\right)$ : $1576(\mathrm{C}=\mathrm{C}), 1620(\mathrm{C}=\mathrm{N}), 3191(\mathrm{NH}) ;{ }^{1} \mathrm{H}-\mathrm{NMR} \quad(300 \mathrm{MHz}$, $\left.{ }_{D M S O}-\mathrm{d}_{6}, \delta \quad(\mathrm{ppm})\right):$ 7.149-7.910 (m, 9H, Ar-H), 8.333 (d, 2H, $J=7.5 \mathrm{~Hz}$, Ar-NH, N-CH=N), 8.904 (s, 1H,indole H-2), $11.651(\mathrm{~s}, 2 \mathrm{H}$, indole $\mathrm{NH}, \mathrm{CH}=\mathrm{N})$;Elemental analysis: Calc. for $\mathrm{C}_{16} \mathrm{H}_{13} \mathrm{~N}_{5} \mathrm{O}_{2}$ : C, 62.53; H, 4.38; N, 22.79; found: $\mathrm{C}, 62.81 ; \mathrm{H}, 4.38$; $\mathrm{N}, 22.98 \%$.

\section{$N^{\prime}-((1 H-i n d o l-3-y l)$ methylene)-N-(4-nitrophenyl)formo- hydrazonamide (2e)}

Compound 2e was obtained in the yield of $89 \%$ as yellow crystalline product; M.p. $295^{\circ} \mathrm{C}$; $\mathrm{IR}\left(\mathrm{KBr}, v_{\max }\left(\mathrm{cm}^{-1}\right)\right)$ : $1577(\mathrm{C}=\mathrm{C}), 1619(\mathrm{C}=\mathrm{N}), 3215(\mathrm{NH}) ;{ }^{1} \mathrm{H}-\mathrm{NMR} \quad(300 \mathrm{MHz}$, $\left.D M S O-\mathrm{d}_{6}, \quad \delta \quad(\mathrm{ppm})\right):$ 7.177-7.911 (m, 9H, Ar-H), 8.339 (d, 2H, $J=7.5 \mathrm{~Hz}$, Ar-NH, N-CH=N), 8.907 (s, 1H,indole H-2), 11.653 (s, $2 \mathrm{H}$, indole $\mathrm{NH}, \mathrm{CH}=\mathrm{N}$ ) ; Elemental analysis: Calc. for $\mathrm{C}_{16} \mathrm{H}_{13} \mathrm{~N}_{5} \mathrm{O}_{2}$ : C, 62.53; H, 4.38; N, 22.79; found: C, 62.63; H, 4.27; $\mathrm{N}, 22.82 \%$.

\section{$N^{\prime}$-((1H-indol-3-yl) methylene)-N-(3-methoxyphenyl)-}

formohydrazonamide (2f)

Compound $2 \mathbf{f}$ was obtained in the yield of $75 \%$ as yellow color product; M.p. > $300{ }^{\circ} \mathrm{C}$; IR $\left(\mathrm{KBr}, v_{\max }\left(\mathrm{cm}^{-1}\right)\right)$ : $1576(\mathrm{C}=\mathrm{C}), 1619(\mathrm{C}=\mathrm{N}), 3213(\mathrm{NH}) ;{ }^{1} \mathrm{H}-\mathrm{NMR} \quad(300 \mathrm{MHz}$, $\left.D M S O-\mathrm{d}_{6}, \quad \delta \quad(\mathrm{ppm})\right): \quad 4.087 \quad(\mathrm{~s}, 3 \mathrm{H}, \mathrm{OCH} 3), \quad 7.197-8.020$ $(\mathrm{m}, 9 \mathrm{H}, A r-\mathrm{H}), 8.189(\mathrm{~d}, 2 \mathrm{H}, \quad J=7.5 \mathrm{~Hz}, \operatorname{Ar}-\mathrm{NH}, \mathrm{N}-\mathrm{CH}=\mathrm{N})$, 8.048 (s, 1H,indole $\mathrm{H}-2), 11.952$ (s, 2H, indole $\mathrm{NH}$, $\mathrm{CH}=\mathrm{N}$ ) ;Elemental analysis: Calc. for $\mathrm{C}_{17} \mathrm{H}_{16} \mathrm{~N}_{4} \mathrm{O}: \quad \mathrm{C}$, 69.85; H, 5.52; N, 19.17; found: C, 70.05; H, 5.64; N, $19.31 \%$.

\section{$N^{\prime}$-((1H-indol-3-yl) methylene)-N-(4-methoxyphenyl)- formohydrazonamide (2g)}

Compound $\mathbf{2 g}$ was obtained in the yield of $70 \%$ as yellow crystals; M.p. $290{ }^{\circ} \mathrm{C}$; IR $\left(\mathrm{KBr}, v_{\max }\left(\mathrm{cm}^{-1}\right)\right)$ : $1576(\mathrm{C}=\mathrm{C})$, $1619(\mathrm{C}=\mathrm{N}), 3191(\mathrm{NH}) ;{ }^{1} \mathrm{H}-\mathrm{NMR} \quad\left(300 \mathrm{MHz}, D M S O-\mathrm{d}_{6}, \delta\right.$ (ppm)): 3.805 (s,3H,OCH3), 7.175-7.709 (m, 9H, Ar-H), 8.361 (d, $2 \mathrm{H}, \quad J=7.5 \mathrm{~Hz}, \operatorname{Ar}-\mathrm{NH}, \mathrm{N}-\mathrm{CH}=\mathrm{N}$ ), 8.908 (s, $1 \mathrm{H}$,indole H-2), $11.653(\mathrm{~s}, 2 \mathrm{H}$, indole $\mathrm{NH}, \mathrm{CH}=\mathrm{N})$; Elemental analysis: Calc. for $\mathrm{C}_{17} \mathrm{H}_{16} \mathrm{~N}_{4} \mathrm{O}: \mathrm{C}, 69.85 ; \mathrm{H}, 5.52 ; \mathrm{N}, 19.17$; found: $\mathrm{C}, 70.11 ; \mathrm{H}, 5.63$; $\mathrm{N}, 19.35 \%$.

\section{$N^{\prime}-((1 H-i n d o l-3-y l)$ methylene $)-N-(3-m e t h y l p h e n y l-)$ formohydrazonamide (2h)}

Compound $\mathbf{2 h}$ was obtained in the yield of $67 \%$ as yellow crystalline product; M.p. $300{ }^{\circ} \mathrm{C}$; IR $\left(\mathrm{KBr}, v_{\max }\left(\mathrm{cm}^{-1}\right)\right)$ : $1577(\mathrm{C}=\mathrm{C}), 1620(\mathrm{C}=\mathrm{N}), 3214(\mathrm{NH}) ;{ }^{1} \mathrm{H}-\mathrm{NMR} \quad(300 \mathrm{MHz}$, $\left.D M S O-\mathrm{d}_{6}, \delta(\mathrm{ppm})\right): 3.312(\mathrm{~s}, 3 \mathrm{H}, \mathrm{CH} 3), 7.148-7.812(\mathrm{~m}, 8 \mathrm{H}, \mathrm{Ar}-$ $\mathrm{H}), 8.189(\mathrm{~d}, 2 \mathrm{H}, \quad J=7.5 \mathrm{~Hz}, \operatorname{Ar}-\mathrm{NH}, \mathrm{N}-\mathrm{CH}=\mathrm{N}), 8.900(\mathrm{~s}$, $1 \mathrm{H}$,indole $\mathrm{H}-2), 11.652(\mathrm{~s}, 2 \mathrm{H}$, indole $\mathrm{NH}, \mathrm{CH}=\mathrm{N})$;Elemental analysis: Calc. for $\mathrm{C}_{17} \mathrm{H}_{16} \mathrm{~N}_{4}$ : C, 73.89; H, 5.84; N, 20.27; found: C, 74.13; H, 6.05; N, 20.41\%.

\section{$N^{\prime}-((1 H$-indol-3-yl) methylene)-N-(4-methylphenyl)- formohydrazonamide (2i)}

The Compound $2 \mathbf{i}$ was obtained in the yield of $71 \%$ as yellow crystalline product; M.p. $312^{\circ} \mathrm{C}$; IR $\left(\mathrm{KBr}, v_{\max }\left(\mathrm{cm}^{-1}\right)\right): 1576$ $(\mathrm{C}=\mathrm{C}), 1620(\mathrm{C}=\mathrm{N}), 3212(\mathrm{NH}) ;{ }^{1} \mathrm{H}-\mathrm{NMR} \quad\left(300 \mathrm{MHz}, D M S O-\mathrm{d}_{6}\right.$, $\delta(\mathrm{ppm})): 3.312(\mathrm{~s}, 3 \mathrm{H}, \mathrm{CH} 3), 7.177-7.709(\mathrm{~m}, 8 \mathrm{H}, \mathrm{Ar}-\mathrm{H}), 8.361$ (d, $2 \mathrm{H}, \quad J=7.5 \mathrm{~Hz}, \operatorname{Ar}-\mathrm{NH}, \mathrm{N}-\mathrm{CH}=\mathrm{N}$ ), 8.905 (s, $1 \mathrm{H}$,indole $\mathrm{H}-2$ ), $11.652(\mathrm{~s}, 2 \mathrm{H}$, indole $\mathrm{NH}, \mathrm{CH}=\mathrm{N})$;Elemental analysis: Calc. for $\mathrm{C}_{17} \mathrm{H}_{16} \mathrm{~N}_{4}$ : C, 73.89; H, 5.84; N, 20.27; found: C, 74.11; H, 6.20; $\mathrm{N}, 20.43 \%$.

\section{$N^{\prime}-((1 H$-indol-3-yl) methylene)-N-benzylformohydrazon-amide} (2j)

The Compound $\mathbf{2} \mathbf{j}$ was obtained in the yield of $63 \%$ as yellow crystalline product; M.p. $310{ }^{\circ} \mathrm{C}$; IR $\left(\mathrm{KBr}, v_{\max }\left(\mathrm{cm}^{-1}\right)\right.$ ): $1578(\mathrm{C}=\mathrm{C}), 1620(\mathrm{C}=\mathrm{N}), 3217(\mathrm{NH}) ;{ }^{1} \mathrm{H}-\mathrm{NMR} \quad(300 \mathrm{MHz}$, DMSO-d $\mathrm{d}_{6}, \delta$ (ppm)): 3.312 (s,2H, CH2),7.177-7.709 (m, 9H, Ar$\mathrm{H}), 8.361(\mathrm{~d}, 2 \mathrm{H}, \quad J=7.5 \mathrm{~Hz}, \operatorname{Ar}-\mathrm{NH}, \mathrm{N}-\mathrm{CH}=\mathrm{N}), 8.905(\mathrm{~s}$, $1 \mathrm{H}$,indole $\mathrm{H}-2), 11.652(\mathrm{~s}, 2 \mathrm{H}$, indole $\mathrm{NH}, \mathrm{CH}=\mathrm{N}$ ) ;Elemental analysis: Calc. for $\mathrm{C}_{17} \mathrm{H}_{16} \mathrm{~N}_{4}$ : C, 73.89; H, 5.84; N, 20.27; found: C, 74.01; H, 5.99; N, 20.42\%.

\section{$N^{\prime}-((1 H-i n d o l-3-y l)$ methylene)- $N$-(naphthalen-1- \\ yl)formohydrazonamide (2k)}

Compound $2 \mathbf{k}$ was obtained in the yield of $70 \%$ as yellow crystalline product; M.p. $315 \mathrm{C}$; IR $\left(\mathrm{KBr}, v_{\max }\left(\mathrm{cm}^{-1}\right)\right)$ : $1577(\mathrm{C}=\mathrm{C}), 1620(\mathrm{C}=\mathrm{N}), 3216(\mathrm{NH}) ;{ }^{1} \mathrm{H}-\mathrm{NMR} \quad(300 \mathrm{MHz}$, $D M S O-\mathrm{d}_{6}, \delta$ (ppm)): 7.148-7.488 (m, 9H, Ar-H), $8.361(\mathrm{~d}, 2 \mathrm{H}$, , $J=7.5 \mathrm{~Hz}, \mathrm{Ar}-\mathrm{NH}, \mathrm{N}-\mathrm{CH}=\mathrm{N}$ ), 8.905 (s, 1H,indole H-2), 11.651 (s, $2 \mathrm{H}$, indole $\mathrm{NH}, \mathrm{CH}=\mathrm{N}$ ) ;Elemental analysis: Calc. for $\mathrm{C}_{20} \mathrm{H}_{16} \mathrm{~N}_{4}$ : C, 76.90; H, 5.16; N, 17.94; found: C, 77.14; H, 5.27; N, $17.89 \%$. 


\section{$N^{\prime}-((1 H-i n d o l-3-y l)$ methylene $)-N-($ quinolin-8-yl) formo- hydrazonamide (2l)}

The Compound $\mathbf{2 l}$ was obtained in the yield of $72 \%$ as yellow crystalline product; M.p. $311 \mathrm{C}$; IR (KBr, $\left.v_{\max }\left(\mathrm{cm}^{-1}\right)\right)$ : $1577(\mathrm{C}=\mathrm{C}), 1620(\mathrm{C}=\mathrm{N}), 3216(\mathrm{NH}) ;{ }^{1} \mathrm{H}-\mathrm{NMR} \quad(300 \mathrm{MHz}$, DMSO-d ${ }_{6}, \delta$ (ppm)): 7.150-7.487 (m, 9H, Ar-H), 8.334 (d, 2H, , $J=7.5 \mathrm{~Hz}$, Ar-NH, N-CH=N), 8.902 (s, 1H,indole H-2), 11.654 (s, $2 \mathrm{H}$, indole $\mathrm{NH}, \mathrm{CH}=\mathrm{N}$ ) ;Elemental analysis: Calc. for $\mathrm{C}_{19} \mathrm{H}_{15} \mathrm{~N}_{5}: \mathrm{C}$, 72.83; H, 4.82; N, 22.35; found: C, 73.92; H, 5.61; N, $23.03 \%$.

\section{Anti-inflammatory Activity \\ Animals}

Animals were obtained from the animal house of the Faculty of Pharmacy, Tanta University, Tanta Egypt; all animals were allowed free access to water and were kept on a constant standard diet. All procedures involving animals were carried out in accordance with the guidelines for the care and use of laboratory animals and were approved by the Ethics Committee of the Faculty of Pharmacy, Tanta University, Tanta, Egypt. Adult Wistar strain rats of male sex, weighing 100-140 g, were used for anti-inflammatory activity. The animals were allowed food and water ad libitum except during the experiments. They were housed in wire- mesh cages at $25 \pm 2{ }^{\circ} \mathrm{C}$, with $50 \pm 5 \%$ relative humidity and $12 \mathrm{hr}$ light/dark cycle. The animals were randomly allocated into groups and fasted for 12-24 hours before the experimental study and used for determining the anti-inflammatory activity. All test compounds and the reference drug were administered I.P, suspended in dimethylsulfoxide (DMSO) solution. This study was done by following the procedure of Winter et al. (Winter, et al., 1962). The rats were divided into three groups (control, tested compounds and standard drug) of six animals each. A freshly prepared suspension of carrageenan ( $1.5 \%$ in $0.9 \%$ saline), $0.1 \mathrm{~mL}$ was injected S.C. into the subplantar region of the right hind paw of each rat. The test compounds and standard drug were administered I.P at the dose of $0.2 \mathrm{mmole} / \mathrm{Kg}$ to the animals of tested derivatives groups and the standard drug group, respectively, $2 \mathrm{hr}$ before the carrageenan injection. The paw weight of each rat was measured after $4 \mathrm{hr}$ of carrageenan treatment with the help of a Plethysmometer. The percent antiinflammatory activity was calculated according to the formula given below.

$\%$ Inhibition

$=\frac{\text { Mean edema of control group }- \text { Mean edema of test }}{\text { Mean edema of control group }} \times 100$

\section{Evaluation of cytotoxic activity of target compound}

Anticancer activity evaluation using the Human breast carcinoma cell line (MCF7) was performed in the National Cancer Institute, Cairo University, Cairo, Egypt, using the method of (Skehan, et al., 1990).

Cells were plated in 96-mutiwell plate (10 cells/well) for $24 \mathrm{hr}$ before treatment with the compounds to allow attachment of cell to the wall of the plate. The $100 \mu \mathrm{g} / \mathrm{ml}$ of each compound under test was added to the cell monolayer triplicate wells. Monolayer cells were incubated with each compound for $48 \mathrm{hr}$ at $37^{\circ} \mathrm{C}$ and in atmosphere of $5 \% \mathrm{CO}_{2}$. After $48 \mathrm{hr}$, cells were fixed, washed and stained with Sulfo-Rhodamine-B stain. Excess stain was washed with acetic acid and attached stain was recovered with Tris EDTA buffer. Color intensity was measured in an ELISA reader.

\section{Evaluation of drug likeness}

The drug likeliness was evaluated using the Lipinski rule of 5 via Lipinski drug filter protocol (Lipinski, 2004) using Molinspiration software (Molinspiration, 2012). Our synthesized target compounds were passed the Lipinski rule of 5 and have properties that would make it a likely orally active drug in humans. The predicted drug likeness score of new compounds were compared with standard drugs indomethacin and doxorubicin as shown in Table 3.

\section{Bioactivity score}

Bioactivity of prepared compounds was checked by calculating the activity score toward $G$ protein coupled receptors (GPCRs) ligand, ion channel modulator, nuclear receptor legend, kinase inhibitor, protease inhibitor and enzyme inhibitor. All the parameters were checked with the help of software Molinspiration drug-likeness score online (Verma, 2012). The predicted bioactivity score of synthesized compounds and indomethacin, doxorubicin as reference drugs were illustrated in Table 4.

\section{Molecular docking studies Protein Preparation}

The three-dimensional crystal structure of enzymes taken from Protein Data Bank (PDB) (http://www.rcsb.org/) is as follows: enzymes COX-1 (PDBID: 3N8Y) (Sidhu, et al., 2010) and COX-2 (PDB ID: 3LN1) (Wang, et al., 2010). All the PDB's were loaded in the Molegro virtual docker (MVD) (Thomsen, et $a l .$, 2009) with the removal of all water molecules and cofactors. The standard Molegro algorithm was utilized for rendering the missing charges, protonation states, and assigning of polar hydrogen to the receptor.

\section{Ligands preparation}

The Structures of ligands were drawn using marvin sketch and energy minimization was done. Energy minimization was done to help the docking program, Molegro Virtual Docker (MVD), (Thomsen, et al., 2009) to identify the bioactive conformer from the local minima. One major advantage of Molegro Virtual Docker (MVD) is that it helps in assigning the missing bond orders, charges, bonds, and hybridization states of the imported ligands.

\section{Molecular docking}

Flexible ligand models were used for docking and postdocking geometry optimizations. The post-docking geometry 
optimizations were carried out using Molegro Virtual Docker (MVD), Simulations the ligand was binding with site of enzymes COX-1 (PDBID: 3N8Y) and COX-2 (PDB ID: 3LN1). A docking sphere (15 $\AA$ radius) was placed on the binding sites of each protein structure in order to allow different orientations of each ligand to be searched in the binding cavities and for multiple protein-ligand poses to be returned. The Root Mean Square Deviation (RMSD) threshold for multiple cluster poses was set at $<1.00 \AA$.

The docking algorithm was set at maximum restoration, of 1500 with a simple evolution population size of 50 and a minimum of 30 runs for each ligand. Each binding site of oligomeric structures was searched, and the lowest energy pose (based on the mol Dock Score and re-rank scores) for each ligand across enzymes COX-1 (PDBID: 3N8Y) and COX-2 (PDB ID: $3 \mathrm{LN1}$ ) structures. The predicted mol Dock Score and re-rank scores for all prepared compounds as lowest energy pose are presented in Table 5.

\section{RESULTS AND DISCUSSION}

The synthetic route used to synthesize title compounds was outlined in Scheme 1. Hyrazone (1), the starting material was prepared according to the method reported in literature (Lohitha, et al., 2011). Hydrazone was condensed with different substituted formamides in ethanol to give the corresponding compounds in good yield.

Reaction of hydrazone with electron withdrawing group at para- position of aromatic formamide was faster and gave better yield than the corresponding meta- substituted ones. Accordingly. the derivatives with electron withdrawing group at para- position for example; p-nitro (2e) had better yield and short refluxing time than p-methoxy and p-chloro (2g and 2c).

Synthesized compounds were purified by column chromatography on silica gel. The IR spectra of synthesized compounds exhibited very similar features as the expected bands for the characteristic groups such as $\mathrm{NH}, \mathrm{C}=\mathrm{N}$, and disappearance of $\mathrm{NH}_{2}$ stretching vibrations. Presence of peak in the region 3191$3217 \mathrm{~cm}^{-1}$ indicates the existence of $\mathrm{NH}$ moiety and that of peak in the region $1619-1620 \mathrm{~cm}^{-1}$ indicates $\mathrm{C}=\mathrm{N}$, in all the compounds.

In the ${ }^{1} \mathrm{H}-\mathrm{NMR}$ spectral data, all protons were seen according to the expected chemical shift and integral values, the aromatic protons appeared as a multiplet peaks within the range 6.8-7.8 $\delta \mathrm{ppm}$, doublet signals for $\mathrm{Ar}-\mathrm{NH}$ and $\mathrm{N}-\mathrm{CH}=\mathrm{N}$ appeared at $8.361 \delta \mathrm{ppm}$. Signals belonging to $-\mathrm{NHNH}_{2}$ of hydrazone are disappeared indicating that functionalization of hydrazone with $\mathrm{N}$ substituted formamide. Elemental analysis data were also in line with theoretical values.

\section{Anti-inflammatory activity}

All the newly synthesized compounds 2a-2l were evaluated for their anti-inflammatory activity against carrageenin- induced paw edema method in rats, using indomethacin as reference drug at a dose of $0.2 \mathrm{mmol} / \mathrm{kg}$ I.P. Percent of the edema inhibition was calculated after $4 \mathrm{hr}$ of carrageenin treatment. The tested compounds showed good anti-inflammatory activity ranging between $72.3-89.3 \%$. The results were tabulated in Table1.

Table1: Anti-inflammatory activity of the tested compounds.

\begin{tabular}{ccc}
\hline Comp. No. & Dose $(\mathbf{m m o l} / \mathbf{K g})$ & $\begin{array}{c}\text { Anti-inflammatory activity(\% } \\
\text { inhibition } \pm \text { SEM })\end{array}$ \\
\hline $2 \mathrm{a}$ & 0.2 & $72.30 \pm 1.51$ \\
$2 \mathrm{~b}$ & 0.2 & $76.00 \pm 1.82$ \\
$2 \mathrm{c}$ & 0.2 & $76.50 \pm 1.78$ \\
$2 \mathrm{~d}$ & 0.2 & $87.70 \pm 1.52$ \\
$2 \mathrm{e}$ & 0.2 & $89.30 \pm 1.53$ \\
$2 \mathrm{f}$ & 0.2 & $79.50 \pm 1.65$ \\
$2 \mathrm{~g}$ & 0.2 & $80.70 \pm 1.75$ \\
$2 \mathrm{~h}$ & 0.2 & $74.90 \pm 1.69$ \\
$2 \mathrm{i}$ & 0.2 & $75.20 \pm 1.56$ \\
$2 \mathrm{j}$ & 0.2 & $73.50 \pm 1.95$ \\
$2 \mathrm{k}$ & 0.2 & $72.65 \pm 1.56$ \\
$2 \mathrm{l}$ & 0.2 & $72.50 \pm 1.52$ \\
Indomethacin & 0.2 & $46.00 \pm 1.92$ \\
Control & $0.1 \mathrm{ml}$ DMS & --- \\
\hline
\end{tabular}

On comparison, standard drug indomethacin showed $46 \%$ inhibition after $4 \mathrm{hr}$ of treatment. Among the tested compounds, $\mathbf{2 d}\left(\mathrm{m}-\mathrm{NO}_{2}\right), \mathbf{2} \mathbf{e}\left(\mathrm{p}-\mathrm{NO}_{2}\right)$ and $\mathbf{2} \mathbf{g}\left(\mathrm{p}-\mathrm{OCH}_{3}\right)$ may be considered as potent anti-inflammatory agents (edema reduction percent: $89.3 \%, 87.7 \%$ and $80.7 \%$ respectively), while indomethacin was $46 \%$. On the other hand, the derivative with electron withdrawing group at para-position such as $\mathbf{2 e}\left(\mathbf{p}-\mathbf{N O}_{2}\right)$ showed somewhat high anti-inflammatory activity $(89.3 \%)$ compared with the other position such as meta- positions $(87.7 \%)$ e.g. $2 \mathbf{d}\left(\mathbf{m}-\mathrm{NO}_{2}\right)$. These gave an indication that, the nature and the position of substituent effect on the activities of the prepared compounds.

\section{Evaluation of cytotoxic activity of target compounds}

The synthesized target compounds were evaluated for their cytotoxic activity in vitro against Human breast carcinoma cell line (MCF7) using doxorubicin as a reference compound. The results of single dose experiment $(100 \mu \mathrm{g} / \mathrm{ml})$ of synthesized compounds performed on Human breast carcinoma cell line (MCF7) were represented in Table 2.

From the results found that the compounds $\mathbf{2 f}$ and $\mathbf{2 j}$ exhibited the percent of inhibition 61.5 and $68 \%$ respectively at the dose $100 \mu \mathrm{g} / \mathrm{ml}$. While, the rest of compounds showed less activity (the percent of inhibition were ranged between $0-20.5$ $\%)$. Also, the derivatives at meta- position had higher activity than derivatives at para-position. For example, the m-methoxy derivative (2f) has inhibition percent at $100 \mu \mathrm{g} / \mathrm{ml}$ equal $61.5 \%$; while the p-methoxy derivative $(\mathbf{2 g})$ has inhibition percent $=0 \%$ at the same dose. 
Table 2: Cytotoxic activity screening on MCF-7 cell line $(100 \mu \mathrm{g} / \mathrm{ml})$.

\begin{tabular}{|c|c|c|c|c|c|c|c|c|c|c|c|c|}
\hline Sample No. & $\mathbf{2 a}$ & $2 \mathrm{~b}$ & $2 \mathrm{c}$ & 2d & $2 \mathrm{e}$ & $2 f$ & $2 \mathrm{~g}$ & $2 \mathrm{~h}$ & $2 \mathrm{i}$ & $2 \mathbf{j}$ & $2 \mathbf{k}$ & 21 \\
\hline Inhibition\% & 20.5 & 15 & 5 & 20 & 17 & 61.5 & 0 & 5 & 15 & 68 & 15 & 13 \\
\hline
\end{tabular}

Table 3: Drug likeness score for the tested compounds compared with indomethacin and doxorubicin.

\begin{tabular}{|c|c|c|c|c|c|c|c|c|}
\hline Compd.No. & TPSA $\left(\mathbf{A}^{2}\right)$ & n.rotb & NA & miLogP & n ON & n OHNH & NV & MW \\
\hline Rule & $<160$ & $<10^{1}$ & $20-70^{2}$ & $\leq 5$ & $<<10$ & $<5$ & $\leq 1$ & $<500$ \\
\hline $2 a$ & 52.55 & 4 & 20 & 3.23 & 4 & 2 & 0 & 262.32 \\
\hline $2 b$ & 52.55 & 4 & 21 & 3.89 & 4 & 2 & 0 & 296.76 \\
\hline $2 \mathrm{c}$ & 52.55 & 4 & 21 & 3.91 & 4 & 2 & 0 & 296.76 \\
\hline $2 \mathrm{~d}$ & 98.37 & 5 & 23 & 3.17 & 7 & 2 & 0 & 307.31 \\
\hline $2 \mathrm{e}$ & 98.37 & 5 & 23 & 3.19 & 7 & 2 & 0 & 307.31 \\
\hline $2 \mathrm{f}$ & 61.78 & 5 & 22 & 3.27 & 5 & 2 & 0 & 292.34 \\
\hline $2 g$ & 61.78 & 5 & 22 & 3.29 & 5 & 2 & 0 & 292.34 \\
\hline $2 \mathrm{~h}$ & 52.55 & 4 & 21 & 3.66 & 4 & 2 & 0 & 276.34 \\
\hline $2 \mathrm{i}$ & 52.55 & 4 & 21 & 3.68 & 4 & 2 & 0 & 276.34 \\
\hline $2 \mathrm{j}$ & 52.55 & 5 & 21 & 2.94 & 4 & 2 & 0 & 276.34 \\
\hline $2 \mathrm{k}$ & 52.55 & 4 & 24 & 4.39 & 4 & 2 & 0 & 312.38 \\
\hline 21 & 65.44 & 4 & 24 & 3.19 & 5 & 2 & 0 & 313.36 \\
\hline Indomethacin & 59.30 & 3 & 23 & 3.95 & 4 & 1 & 0 & 327.77 \\
\hline Doxorubicin & 206.08 & 5 & 39 & 0.57 & 12 & 7 & 3 & 543.52 \\
\hline
\end{tabular}

$1=($ Veber, et al., 2002), $2=$ (dProperties user`s manual, 2011)

Notes: TPSA: Total molecular polar surface area; n.rotb:number of rotatable bonds; N A:number of atoms; Milog P: partition coefficient; n ON: number of hydrogen acceptor; nONH: number of hydrogen donor, NV: number of violation of five Lipinsky rules; MW: molecular weight and DLMS: Drug likness model score.

Table 4: Bioactivity score of the tested compounds compared with indomethacin and doxorubicin.

\begin{tabular}{|c|c|c|c|c|c|c|}
\hline Compound & GPCR ligand & Ion channel modulator & Kinase inhibitor & Nuclear receptor ligand & Protease inhibitor & Enzyme inhibitor \\
\hline $2 \mathrm{a}$ & -0.1955 & -0.4883 & -0.2808 & -0.4442 & -0.4834 & -0.0614 \\
\hline $2 b$ & -0.1671 & -0.4775 & -0.2481 & -0.4203 & -0.5089 & -0.1214 \\
\hline $2 \mathrm{c}$ & -0.1553 & -0.4724 & -0.2578 & -0.4132 & -0.4709 & -0.098 \\
\hline $2 d$ & -0.2783 & -0.5087 & -0.3325 & -0.462 & -0.4873 & -0.1772 \\
\hline $2 \mathrm{e}$ & -0.2617 & -0.4796 & -0.3451 & -0.4074 & -0.4711 & -0.1631 \\
\hline $2 \mathrm{f}$ & -0.1919 & -0.549 & -0.237 & -0.3866 & -0.455 & -0.1309 \\
\hline $2 g$ & -0.1761 & -0.5382 & -0.2477 & -0.3575 & -0.4337 & -0.1143 \\
\hline $2 \mathrm{~h}$ & -0.2169 & -0.5696 & -0.2871 & -0.4252 & -0.4974 & -0.1485 \\
\hline $2 \mathrm{i}$ & -0.2036 & -0.5556 & -0.2906 & -0.4222 & -0.4881 & -0.129 \\
\hline $2 \mathrm{j}$ & -0.0445 & -0.3596 & -0.2094 & -0.3164 & -0.3376 & -0.0658 \\
\hline $2 \mathrm{k}$ & -0.0427 & -0.3124 & -0.1174 & -0.2695 & -0.2607 & -0.0127 \\
\hline 21 & -0.0119 & -0.3371 & -0.1352 & -0.3534 & -0.2913 & 0.024 \\
\hline Indomethacin & 0.30 & -0.25 & -0.11 & -0.44 & -0.07 & 0.36 \\
\hline Doxorubicin & 0.20 & -0.20 & -0.07 & 0.32 & 0.67 & 0.66 \\
\hline
\end{tabular}

\section{Evaluation of drug likeliness}

Lipinski's rule of five or simply the Rule of five (RO5) is a rule of survey and to evaluate drug likeness (physical-chemical properties) or determine if a chemical compound will be orally bioavailable (Lipinski, 2004). The drug likeness was calculated and discussed on the basis of Lipinski's rule and its component for all prepared compounds using Molinspiration software "on-line test". The results were summarized in Table 3. The physicalchemical properties including: an octanol-water partition coefficient (Milog P) $<5$ that means these shows good permeability across cell membrane, polar surface area (TPSA) < $160 \AA$ Á2 which shown to be a very good descriptor characterizing drug absorption, number of violation ( $n$ violations) $=1$ or $<0$ it means compound easily bind to receptor, molecular weight (MW) $<500$, number of rotatable bonds $(\boldsymbol{n}$ rotb) $<10$ this measures molecular flexibility (Veber, et al., 2002), number hydrogen bond donors (n $\mathbf{O H N H}) \leq 5$ (The sum of $\mathrm{OHs}$ and $\mathrm{NHs}$ ), number
$(\mathrm{MW})>500$, total molecular polar surface area $(\mathrm{TPSA})>160 \mathrm{~A}^{\mathrm{o2}}$ and hydrogen bond acceptors $(\mathbf{n O N})>7$, so doxorubicin has $\mathrm{n}$ violations $(\mathbf{N V})=\mathbf{3}$, as shown in Table 3. From the results reveal that these compounds are orally bioactive because they possess groups which act as substrate for transporter.

\section{Bioactivity score}

Similarly, all compounds were taken for calculation of bioactivity score towards G protein-coupled receptors (GPCR) ligands, ion channel modulator, kinase inhibitors, nuclear receptor inhibitors and other enzyme targets based on Molinspiration software "on-line test". These bioactivity results were summarized in Table 4. The scores allowed adequate identification of active, moderately active or inactive molecules. If the bioactivity scores is $(\geq 0.00)$ may refer to considerable biological activities, if the bioactivity scores $(-5.0$ to 0.0$)$ it is moderately active and finally if the bioactivity scores $(<-5.0)$ it is inactive. Consequently, the 
results showed the following observations: a) GPCR ligand: all our compounds were found to be moderately bioactive, the bioactivity scores $(-0.0119$ to -0.2783$)$ comparing with indomethacin and doxorubicin (0.30 and 0.20$)$ respectively. b) ion channel modulator: all our compounds were found to be better bioactive, the bioactivity scores ( -0.3124 to -0.5696$)$ comparing with indomethacin and doxorubicin $(-0.25$ and -0.20$)$ respectively. c) kinase inhibitors: all our compounds were found to be moderately bioactive the bioactivity scores $(-0.1174$ to -0.3451$)$ comparing with indomethacin and doxorubicin (-0.11 and -0.07) respectively. d) nuclear receptor inhibitors: in comparison with indomethacin and doxorubicin the bioactivity scores were -0.44 and 0.32 respectively whereas our compounds were found to be moderately bioactive with the bioactivity scores $(-0.2695$ to -0.4252$)$. e) Protease inhibitor: all our compounds were found to be moderately bioactive, the bioactivity scores $(-0.2607$ to -0.5089$)$, while indomethacin and doxorubicin were -0.07 and 0.67 respectively. f) Enzyme inhibitor: all our compounds were found to be better bioactive; the bioactivity scores were ranged between 0.024 to 0.1772 , whereas indomethacin and doxorubicin were 0.36 and 0.66 respectively.

The results herein are well below the limits of bioactivity score (-0.5089 to 0.024) (Table 4). In addition, the designed molecules obeyed the Lipinski rule of five. So the designed molecules may be useful as a lead compound for various diseases like depression, anti inflammatory, cancer and others diseases.

\section{Molecular docking studies}

Molecular docking study was performed to investigate the binding affinities and interaction modes between our compounds and the target enzymes using the Molegro Virtual Docker (MVD). All prepared compounds were incorporated in the active site of the enzymes isoform COX-1 (PDBID: 3N8Y) and isoform COX-2 (PDB ID: 3LN1). The docking scores were expressed in negative energy terms; the lower binding free energy is the better binding affinity. In addition, the docking scoring function of Mol Dock is an extension of the piecewise linear potential (PLP) including new hydrogen bonding and electrostatic terms. To further improve docking accuracy, a re-ranking scoring function is introduced. Subsequently, Mol Dock score and re-rank score were indicated in Table 5. The docking study displayed that most of the prepared compounds showed promising affinity to inhibit both cox-1 and cox-2. Thus, the synthesized compounds showed good docking scores ranged from -129.601 to -148.276 with cox-1 and from 92.797 to -108.757 with cox-2. From Table 5 appears that the compounds $\mathbf{2 d}$ and $\mathbf{2 e}$ are considered as good anti-inflammatory agents because they have good mol dock scores of -146.71 and 148.276 with the active site of cox- 1 and -104.223 , and -108.757 with cox-2 enzymes respectively. While indomethacin showed dock score of -131.578 and 92.5925 with cox-1 and cox-2 respectively. According to docking analysis the most active ligand showed good binding interactions in terms of hydrogen bond and hydrophobic interactions with the residues of proteins amino acids. From the results, compound $\mathbf{2 d}$ indicated hydrogen bond interaction with Arg-374, Arg-376, Asp-375 and Phe-142 and compound 2e displayed hydrogen bond interaction with Arg-374, Arg-376, Arg-375 and Gly-225 with cox-1, whereas, the reference compounds (indomethacin) showed hydrogen bond with Arg-374, Arg-376 and electrostatic with Arg-374, Arg-376 as represented in Fig.1 (a). While with cox-2, compound 2d showed hydrogen bond interaction with Lys-239, Ser-549, and His-228 and Lys-346, while compound 2e showed hydrogen bond interaction with Ser549 and His-228 and Lys-239, whereas, the reference compounds (indomethacin) showed hydrogen bond with Lys-346, Lys-328, Phe-347 and Asn-546 as indicated in Fig.1 (b). These results are further supported to the anti-inflammatory activity in vivo as illustrated in Table1 which revealed that the most active compounds ( $2 \mathrm{~d}$ and $2 \mathrm{e}$ ) showed edema reduction percent of $89.3 \%, 87.7 \%$. So, all the compounds exhibited a good docking score which were agreed and supported to the in- vivo anti inflammatory activity of these compounds.

Table 5: Docking parameters in active site of the enzymes COX-1 and COX-2.

\begin{tabular}{|c|c|c|c|c|c|c|}
\hline \multirow{2}{*}{$\begin{array}{c}\text { Comp. No. } \\
--\end{array}$} & \multicolumn{3}{|c|}{ COX1 (PDBID:3N8Y) } & \multicolumn{3}{|c|}{ COX2 (PDBID: 3LN1) } \\
\hline & MolDock Score & Rerank Score & HBond & MolDock Score & Rerank Score & HBond \\
\hline $2 \mathrm{a}$ & -135.364 & -101.479 & -3.49179 & -95.6503 & -77.5339 & -3.58658 \\
\hline $2 b$ & -135.473 & -107.778 & -6.58101 & -98.1905 & -81.0321 & -1.24095 \\
\hline $2 \mathrm{c}$ & -145.331 & -109.715 & -12.6375 & -100.149 & -79.33533 & -2.38313 \\
\hline $2 d$ & -146.71 & -117.051 & -1.97263 & -104.223 & -83.358 & -2.24342 \\
\hline $2 \mathrm{e}$ & -148.276 & -120.943 & -4.33694 & -108.757 & -86.7309 & -4.61197 \\
\hline $2 f$ & -147.244 & -120.904 & -2.89968 & -101.766 & -79.7038 & -2.44933 \\
\hline $2 g$ & -146.609 & -115.266 & -1.37099 & -103.341 & -85.4336 & -4.9669 \\
\hline $2 \mathrm{~h}$ & -132.632 & -98.1926 & -1.66236 & -101.556 & -83.7274 & -2.5 \\
\hline $2 \mathrm{i}$ & -133.938 & -105.889 & -5.76098 & -99.8144 & -76.3131 & -1.89478 \\
\hline $2 \mathrm{j}$ & -129.601 & -104.951 & -1.18736 & -92.7975 & -77.0203 & -2.29506 \\
\hline $2 \mathrm{k}$ & -134.909 & -108.209 & -1.24076 & -108.672 & -91.1389 & -2.79118 \\
\hline 21 & -137.025 & -110 & -0.926841 & -129.807 & -111.192 & -3.13262 \\
\hline Indomethacin & -131.578 & -89.1398 & -2.54039 & -92.5925 & -75.9437 & -1.44338 \\
\hline
\end{tabular}



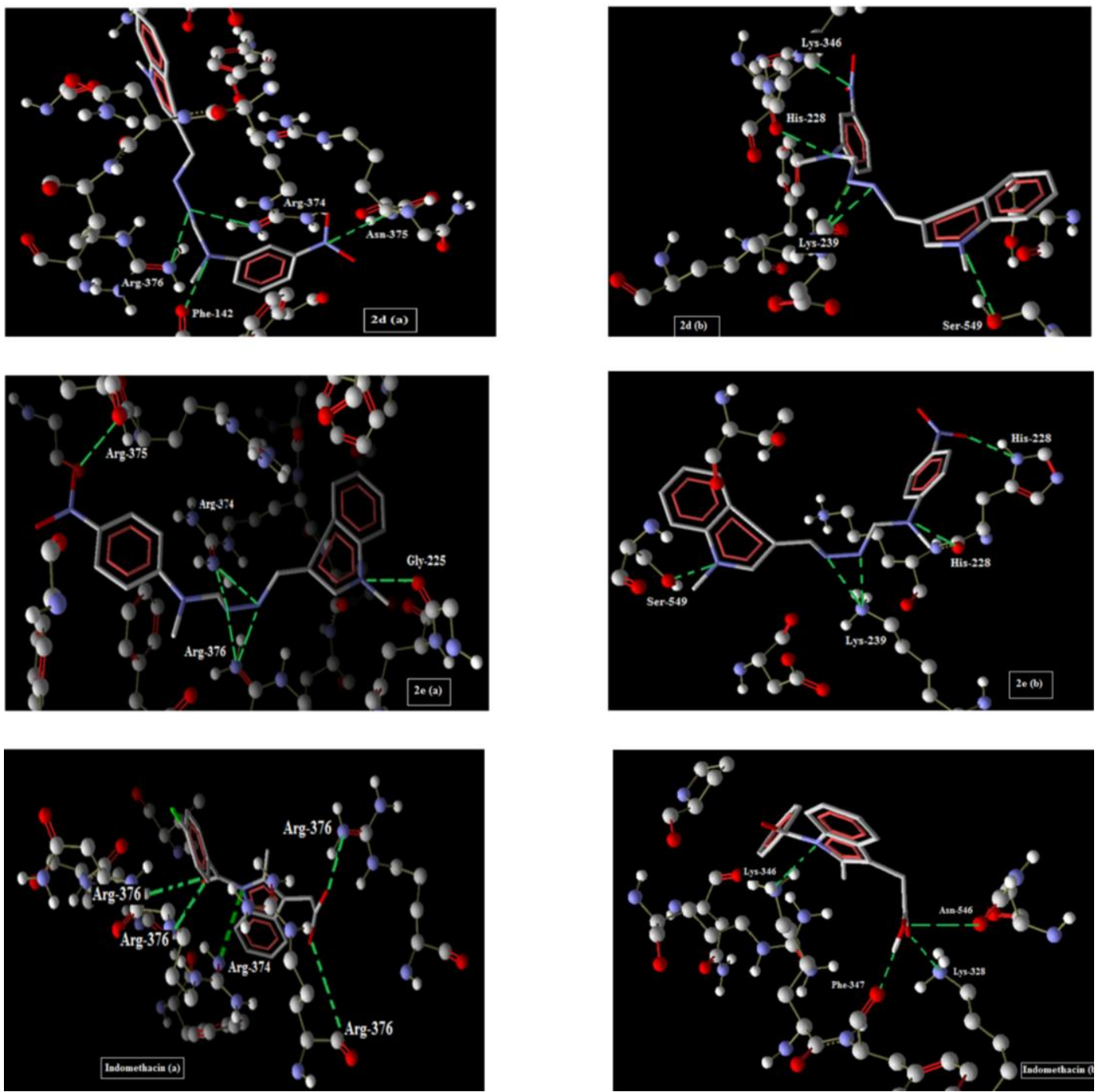

Fig. 1: The Interaction between the compounds 2d, 2e and infomethacin with the active site of cox-1 (a) and cox-2 (b).

\section{CONCLUSIONS}

We described herein the synthesis and characterization of indole-hydrazone derivatives. The structures of the new compounds were confirmed by means of different spectroscopic methods and by elemental analyses. On the basis of preliminary screening data for these new compounds, in vivo anti inflammatory and cytotoxic activity, were evaluated. Results revealed that the most compounds have remarkable anti inflammatory activity, edema reduction percent ranged between $72.3-89.3 \%$, while compounds $\mathbf{2 f}$ and $\mathbf{2 j}$ showed mild cytotoxic activity. Moreover, to help understand the interactions between the ligands and enzyme active sites, the molecular docking studies were carried out for all the synthesized compounds toward active site of cox-1 and cox-2 enzymes and compared the docking score with references drug (indomethcin). The results appeared that, all the compounds exhibited good docking score which are agreed and supported to the in vivo anti inflammatory activity of these compounds. In addition, to recognize the relationship between the physicochemical properties and bioactivity observed for these compounds the drug likeness and bioactivity are calculated using Molinspiration software. All synthesized compounds showed a good drug likeness and bioactivity score comparing with indomethacin and doxorubicin.

\section{Financial support and sponsorship: Nil.}

Conflict of Interests: There are no conflicts of interest.

\section{REFERENCES}

Aisen, P.S., Evaluation of selective COX-2 inhibitors for the treatment of Alzheimer's disease, J Pain Symptom Manage., 2002, 23, 4 , S35-40.

Babahan I., Coban E. P. and Biyik H., Synthesis, characterisation and antimicrobial activities of vic-dioxime derivatives containing heteroaromatic hydrazone groups and their metal complexes, Maejo Int. J. Sci. Technol., 2013, 7 ( 01): 26 - 41. 
Bhaskar V.H., Subramaniyam S., Thakor R. S., and Jayakar B., Synthesis and antimicrobial screening of 2-methyl- 3-[5-substituted phenyl-1,3,4-oxadiazol-2-yl]-1H-indoles, Asian J Chem, 2007, 19(6): 4758-62.

Bhati S. K., A. Kumar, Synthesis of new substituted azetidinoyl and thiazolidinoyl-1,3,4-thiadiazino (6,5-b) indoles as promising antiinflammatory agents, Eur J Med Chem, 2008, 43(11): 2323 - 30.

Chan TA. , Nonsteroidal anti-inflammatory drugs, apoptosis, and colon-cancer chemoprevention, Lancet Oncol, 2002, 3: 166-74.

Da Silva C. M. , da Silva D. L., Modolo L. V. , Alves R. B. , de Resende M. A. , Martins C. V.B. , de Fátima Â., Schiff bases: A short review of their antimicrobial activities, Journal of Advanced Research, 2011, 2(1): 1-8.

Dannhandt G., Kiefer W.: Cyclooxygenase inhibitors--current status and future prospects, Eur. J. Med. Chem. 2001, 36: 109.

dProperties user`s manual 2011, Drug-like indices, Available at: http://www.talete.mi.it/help/dproperties_help/index.html?drug_like_indice s.htm, [Accessed: 2013, talete]

Estevão M.S., Carvalho L.C., Ribeiro D., Couto,D., Freitas M., Gomes A., Ferreira L.M., Fernandes E., Marques M.M., Antioxidant activity of unexplored indole derivatives: synthesis and screening, Eur J Med Chem., 2010, 45(11),4869-78.

Guiqing, X., Jinglin, Z., Yuqin, J., Peng, Z., Wei, L., Design, synthesis and antifungal activity of novel indole derivatives linked with the 1,2,3-triazole moiety via the CuAAC click reaction, J. Chem.1 Research, 2016,40, 5, 257-319.

Hemalatha K., Madhumitha G., , Roopan S, M, Indole as a Core Anti-Inflammatory Agent-A Mini Review, Chem Sci Rev Lett, 2013, 2(5): 287-292.

Karekal,M. R., Birada,V.r, and MathadaM. B. H., Synthesis, Characterization, Antimicrobial, DNA Cleavage, and Antioxidant Studies of Some Metal Complexes Derived from Schiff Base Containing Indole and Quinoline Moieties, Bioorg Bioinorg. Chem. and Appl., 2013, 2013:Article ID 315972, 16 pages.

Kumar N.M. and Kumar D., Recent developments on synthetic indole as potent anticancer agents, Chem. And Biology Interface, 2013, 3(5): 276-303.

Kuz'min V. E.; Artemenko A. G.; Lozytska R. N.; edtchouk A. S.; Lozitsky V. P.; Muratov E. N.; Mescheriakov A. K. Investigation of anticancer activity of macrocyclic Schiff bases by means of 4D-QSAR based on simplex representation of molecular structure. SAR QSAR Environ. Res. 2005,16: 219-230.

Lipinski C.A., Lead- and drug-like compounds: the rule-of-five revolution, Drug Discovery Today: Technologies, 2004,1: 337-341.

Lohitha P., Giles D., Sreedhar C., Sandhya B., Shravani A., Sunitha T., and Kumari R., synthesis and pharmacological evaluation of schiff's and mannich bases of indole derivatives, RGUHS J. of Pharm. Sci., 2011, 1(1): 69-78.

Macdonough MT, Strecker TE, Hamel E, Hall J.J., Chaplin DJ, Trawick M.L, Pinney K.G. Synthesis and biological evaluation of indole-based, anti-cancer agents inspired by the vascular disrupting agent 2-(3'-hydroxy-4'-methoxyphenyl)-3-(3",4",5"-trimethoxybenzoyl)-6methoxyindole , Bioorg Med Chem. 2013, 1 (21): 6831-43.

Molinspiration cheminformatics [homepage on the internet], Novaulica, SK-900 26 Slovensky Grob, Slovak Republic; Available from http://www.molinspiration.com, [cited 2012 July 3].

Pratico DE., Digne J.M.: Selective cyclooxygenase-2 inhibitors development in cardiovascular medicine, Circulation, 2005, 112: 1073.

Rollas S., KucukGuzel S. G. Biological Activities of Hydrazone Derivatives, Molecules, vol. 2007, 12: 1910.

Santos SA, Lukens AK, Coelho L, Nogueira F, Wirth DF, Mazitschek R , Moreira R, Paulo A, Exploring the 3-piperidin-4-yl$1 \mathrm{H}$-indole scaffold as a novel antimalarial chemotype, Eur. J. Med. Chem.; 2015, 102: 320-333.
Sidhu R.S., Lee J.Y., Yuan C., Smith W. L., Comparison of Cyclooxygenase-1 Crystal Structures: Cross-Talk between Monomers Comprising Cyclooxygenase-1 Homodimers, Biochem., 2010,49: 70697079 .

Skehan P., Storeng R., Scudiero D., Monks A., McMahon J., Vistica D., Warren J.T., Bokesch H., Kenney S., Boyd M.R., New colorimetric cytotoxicity assay for anticancer-drug screening, J Natl Cancer Inst., 1990, 82(13): 1107-12.

Sondhi S. M., Dinodia M., and Kumar A., Synthesis, antiinflammatory and analgesic activity evaluation of some amidine and hydrazone derivatives, Bioorg Med Chem, 2006, 14(13): 4657 - 63.

Thomsen, R.; Christensen, M. Molegro Virtual Docker 4.0 User Manual; Molegro ApS: Aarhus, Denmark; 2009: 125-133.

Thun M.J., Henley SJ, Patrono C., Nonsteroidal antiinflammatory drugs as anticancer agents: mechanistic, pharmacologic, and clinical issues. J Natl Cancer Inst, 2002, 94: 252-66.

Tichý M.; Pohl R.; Xu H. Y.; Chen Y.-L.; Yokokawa F.; Shi P.Y.; Hocek M.: "Synthesis and antiviral activity of 4,6-disubstituted pyrimido[4,5-b]indole ribonucleosides" Bioorg. Med. Chem., 2012, 20: 6123-6133.

Tiwari, R K.., Singh D., Singh J., Yadav V., K. Pathak A., Dabur R., K.Chhillar A., Singh R., Sharma G.L., Chandra R.. and Verma A. K., Synthesis and antibacterial activity of substituted 1, 2, 3, 4tetrahydropyrazino [1, 2-a] indoles, ,Bioorg Med. Chem. Lett, 2006, 16 (2): 413-6.

Vashi K.; Naik H. B., Synthesis of novel Schiff base and azetidinone derivatives and their antibacterial activity. Eur J. Chem. 2004, 1: 272-276.

Veber D.F., Johnson S.R., Cheng H.Y., Smith B.R., Ward K. W., Kopple K.D., Molecular properties that influence the oral bioavailability of drug candidates., J Med Chem; 2002, 45(12): 2615 2623.

Verma A., Lead finding from Phyllanthus debelis with hepatoprotective potentials, Asian Pacific J. Trop. Biomed. 2012, 3: S1735-S1737.

Vinusha, H.M. , Shiva, Prasad, K. , Chandan, S. and Muneera, Begum, Imino-4-Methoxyphenol Thiazole Derived Schiff Base Ligands: Synthesis, Spectral Characterization and Antimicrobial Activity, Chem. Sci. J., 2015, 6:3. doi:10.4172/2150-3494.1000102.

Wang J.L.,Limburg D.,Graneto M.J.,Springer J.,Hamper J.R.,Liao S.,Pawlitz J.L.,Kurumbail R.G.,Maziasz T.,Talley, J.J.,Kiefer, J.R.,Carter, The novel benzopyran class of selective cyclooxygenase-2 inhibitors. Part 2: The second clinical candidate having a shorter and favorable human half-life., J. Bioorg. Med.Chem.Lett., 2010, 20: 71597163 .

Winter C.A., Risley E.A., Nuss G.W., Carrageenan-induced edema in hind paw of the rat as an assay for anti-inflammatory drugs, Proc. Soc. Exp. Biol. Med., 1962, 111: 544-547.

How to cite this article:

Sharaf El-Din N., Barseem A. Synthesis, bioactivity and Docking Study of Some New Indole-hydrazone Derivatives. J App Pharm Sci, 2016; 6 (12): 075-083. 